\title{
Profil dan Prevalensi Blastocystis hominis di Laboratorium Parasitologi Fakultas Kedokteran Universitas Kristen Indonesia
}

\author{
Ronny,* Nadia L. Destifani, Edho Yuwono, Forman E.Siagian, Retno Wahyuningsih \\ Departemen Parasitologi Fakultas Kedokteran Universitas Kristen Indonesia
}

\begin{abstract}
Abstrak
Blastocystis hominis merupakan emerging disease yang terdistribusi luas di dunia, dengan prevalensi $10 \%$ di negara maju hingga $60 \%$ di negara berkembang. Perannya sebagai mikroorganisme patogen masih kontroversial. Diduga angka kejadian B. hominis lebih banyak didapatkan pada curah hujan yang rendah dan daerah tropis/ sub-tropis. Penelitian dilakukan untuk mengetahui prevalensi, profil $B$. hominis di Laboratorium Parasitologi Fakultas Kedokteran Universitas Kristen Indonesia, serta hubungan antara angka kejadian infeksi $B$. hominis dengan curah hujan dan kelembaban pada musim penghujan dan kemarau. Penelitian potong lintang deksriptif berdasarkan data pemeriksaan feses di Laboratorium Parasitologi Fakultas Kedokteran Universitas Kristen Indonesia selama 20 tahun sejak Januari 2000 sampai dengan Desember 2019. Sampel feses diperiksa dari sediaan basah dengan pewarnaan eosin dan lugol, dan hasilnya dilaporkan dengan sistem skoring semi kuantitatif. Data curah hujan dan kelembaban didapatkan dari Badan Meteorologi Klimatologi dan Geofisika Stasiun Meteorologi Kemayoran Jakarta.Didapatkan 3270 sampel, dengan hasil sampel positif $B$. hominissebanyak 440 sampel (14\%), Prevalensi pada perempuan lebih tinggi dibandingkan laki-laki dan terbanyak pada kelompok usia 21-60 tahun (67,4\%). Persentase tertinggi ditemukan pada feses dengan konsistensi cair. Tidak ditemukan hubungan antara prevalensi infeksi B. hominis dengan curah hujan $(P=0,285)$ dan kelembaban $(P=0,204)$.
\end{abstract}

Kata kunci: prevalensi, konsistensi, curah hujan, kelembaban, musim

\section{Profile and Prevalence of Blastocystis hominis at Parasitology Laboratory, Medical Faculty Universitas Kristen Indonesia}

\begin{abstract}
Blastocystis hominis is an emerging disease that is widely distributed in the world, with a prevalence of $10 \%$ in developed countries to $60 \%$ in developing countries. Its role as a pathogen is still controversial. It is suspected that the incidence of B. hominis is mostly found in low rainfall and tropical/ sub-tropical areas. The study was conducted to determine the prevalence and profile of B. hominis in the Laboratory of Parasitology, Faculty of Medicine, Universitas Kristen Indonesia.and the relationship between incidence of $B$. hominisinfection with rainfall and humidity in the rainy and dry seasons. This descriptive cross-sectional study was based on fecal examination data at the FK UKI Parasitology Laboratory for 20 years. from January 2000 to December 2019. Stool examination was carried out by making eosin and lugol wet preparations to examine intestinal protozoa, and the results were reported using a semi-quantitative scoring system. Rainfall and humidity data are obtained from the Meteorology, Climatology and Geophysics Agency of the Stasiun MeteorologiKemayoran, Jakarta. As many as3270 samples were obtained, feses with $B$. hominis positive results was 440 samples (14\%). Based on gender, $53.1 \%$ of $B$. hominisinfected were women and most patients were found in the age range from 21 to 60 years $(67.4 \%)$. The highest percentage was found in watery stool. There was no statistically significant between the prevalence of $B$. hominis infection with rainfall $(\mathrm{p}=0.285)$ and humidity $(\mathrm{p}=0.204)$.
\end{abstract}

Key words: prevalence, consistency, rainfall, humidity, season

*R:Penulis Koresponden; E-mail:ronny@uki.ac.id 


\section{Pendahuluan}

Blastocystis hominis merupakan protozoa yang paling sering ditemukan pada feses manusia. ${ }^{1}$ Infeksi parasit pada manusia disebut dengan blastokistosis. Blastokistosis saat ini dikatakan sebagai emerging diseases yang terdistribusi luas di dunia. ${ }^{2}$

Prevalensi blastokistosis cukup tinggi berkisar antara 10\% di negara maju sampai $60 \%$ dinegara berkembang. ${ }^{3}$ Di Filipina, prevalensi B. hominis pada tahun 2012 didapatkan hingga 12,96\% dari 1.271 sampel. ${ }^{1}$ Sementara di Singapura, prevalensi $B$. hominis hanya sebesar $3,3 \% .^{3}$ Di Indonesia sendiri prevalensinya bervariasi, pada penelitian di Padang, prevalensi $B$. hominis sebesar 32,8\% sedangkan di Manado sebesar 39,4\%.,5

Saat ini peran $B$. hominis sebagai patogen belum sepenuhnya dipastikan apakah merupakan parasit penyebab atau hanya sebagai mikroorganisme komensal. ${ }^{6}$ Sementara beberapa penelitian telah menemukan peran patologisnya pada pejamu imunokompromis seperti pasien yang terinfeksi HIV. ${ }^{7}$ Penyebaran $B$. hominis pada manusia melalui jalur oro-fekal dan kolonisasi dari parasit ini dihubungkan dengan higiene yang buruk, kontak dengan hewan dan kontaminasi dari sumber makanan dan minuman. ${ }^{8}$ Walau demikian, Blastocystis sp. juga umum ditemukan pada populasi yang tinggal di negara-negara maju seperti Irlandia dan Denmark. ${ }^{9,10}$

Gejala dari infeksi $B$. hominis bervariasi dan non-spesifik, terbanyak adalah diare dan nyeri abdomen, gejala lain seperti flatulen, anoreksia, nausea dan muntah juga sering ditemukan. ${ }^{11-}$ ${ }^{13}$ Beberapa penelitian melaporkan bahwa angka kejadian blastokistosis berhubungan dengan musim yang lebih panas dan kelembaban yang tinggi. ${ }^{14,15}$ Blastocystis hominis diduga berhubungan dengan curah hujan yang kurang dan kering serta temperatur yang tinggi. ${ }^{14}$ Pada tulisan ini dilaporkan prevalensi, profil demografis pasien yang dinyatakan positif terinfeksi B. hominisdari sampel feses yang diperiksa di Laboratorium Parasitologi Fakultas Kedokteran Universitas Kristen Indonesia (FK UKI) dan hubungannya dengan curah hujan serta kelembaban rata-rata per musim setiap tahunnya dari tahun 2000-2019 yang diambil dari data Badan Meteorologi, Klimatologi dan Geofisika (BMKG) stasiun meteorologi Kemayoran. ${ }^{16}$

\section{Bahan dan cara}

Penelitian ini memakai metode potong lintang deskriptif dengan sumber data hasil pemeriksaan feses di Laboratorium Parasitologi FKUKI selama 18 tahun sejak tahun 2000 sampai tahun 2017. Sampelfeses dikirim ke laboratorium untuk keperluan diagnostik. Pemeriksaan feses dilakukan dengan membuat sediaan basah eosin dan lugol untuk memeriksa protozoa usus. Feses dinyatakan positif bila ditemukan $B$. hominis dalam berbagai bentuk pada sediaan basah eosin maupun lugol. Untuk memudahkan laporan kepada klinisi pengirim, dilakukan skoring semi kuantitatif. Jumlah parasit dinyatakan +1 bila ditemukan 110 parasit/100 lapangan pandang besar (LPB), +2 bila ditemukan 11-100 parasit/100 LPB , +3 jika ditemukan 1-10/1 LPB dan +4 bila jumlah parasit $>10 / 1$ LPB dengan pembesara mikroskoskop 400x.

Analisis data menggunakan Statistical Package for Social Sciences (SPSSversi 15), untuk melihat hubungan curah hujan dan kelembaban berdasarkan musim di daerah Jakarta dengan sampel yang sudah dinyatakan positif infeksi B. hominisper musim antara tahun 2000-2019 dan model regresi logistik ganda dilakukan untuk mengidentifikasi prediktor infeksi yang signifikan dengan nilai $p<0,05$ dianggap secara statistik signifikan. Musim Penghujan 
ditentukan dari bulan Januari-Maret dan Oktober - Desember di tahun yang sama dan musim kemarau ditentukan dari Bulan April - September di tahun tersebut. Data curah hujan dan kelembaban didapatkan seizin Unit Pelaksana Teknis Badan Meteorologi, Klimatologi dan Geofisika (UPT BMKG) dan berasal dari Stasiun Meteorologi Kemayoran.

\section{Hasil}

Sejak Januari 2000-Desember 2019sediaan klinik feses yang diperiksa di Laboratorium Departemen Parasitologi Fakultas Kedokteran UKI berjumlah 3270 sampel. Dari jumlah tersebut sebanyak 440 sampel mengandung $B$. hominis sehingga rerata prevalensi dalam 20 tahun sebesar 13\%. Dari 440 pasien dengan B. hominis, 230 orang adalah perempuan, sementara sisanya yakni 210 orang adalah laki-laki (Gambar 1).

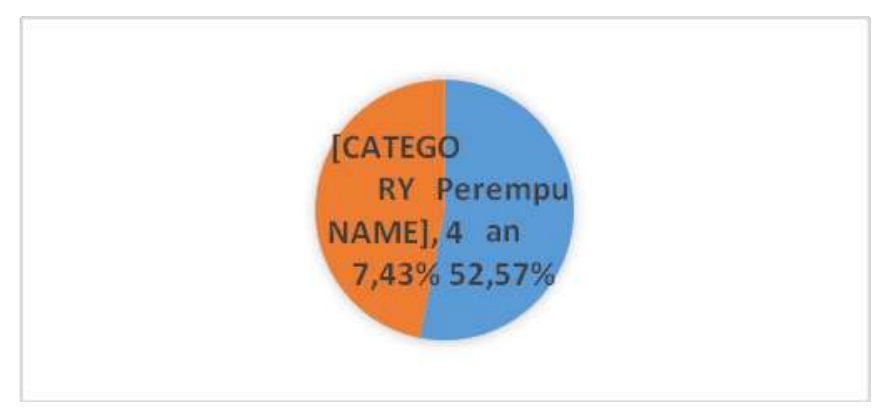

Grafik 1. Prevalensi Blastocystis hominis berdasarkan jenis kelamin

Selama 20 tahun jumlah $B$. hominis yang ditemukan dari feses di laboratorium Parasitologi FK UKI bervariasi dari tahun ke tahun. Hal ini tergantung pada jumlah spesimen yang diperiksa. Seperti pada Tabel 1, jumlah feses yang diperiksa terbanyak adalah pada tahun 2011 yaitu sebanyak 277 sampel, sedangkan paling sedikit pada tahun 2019. Persentase tertinggi sampel feses mengandung $B$. hominis adalah pada tahun 2015 (21\%) dan terendah pada tahun 2019 yaitu hanya 5\% dari keseluruhan sampel yang diperiksakan.

Tabel 1. Prevalensi Blastocystis hominis dalam feses selama 20 tahun

\begin{tabular}{cccc}
\hline Tahun & B. hominis & $\%$ & $\mathrm{n}$ feses \\
\hline 2000 & 5 & 10 & 49 \\
2001 & 10 & 11 & 87 \\
2002 & 17 & 11 & 150 \\
2003 & 14 & 12 & 121 \\
2004 & 12 & 10 & 116 \\
2005 & 20 & 11 & 177 \\
2006 & 20 & 11 & 177 \\
2007 & 23 & 10 & 232 \\
2008 & 38 & 14 & 264 \\
2009 & 43 & 19 & 230 \\
2010 & 34 & 16 & 216 \\
2011 & 52 & 19 & 279 \\
2012 & 37 & 17 & 222 \\
2013 & 30 & 13 & 237 \\
2014 & 18 & 12 & 146 \\
2015 & 22 & 21 & 104 \\
2016 & 13 & 8 & 154 \\
2017 & 21 & 12 & 177 \\
2018 & 9 & 9 & 89
\end{tabular}




\begin{tabular}{cccc}
2019 & 2 & 5 & 43 \\
Jumlah & 440 & 13 & 3270 \\
\hline
\end{tabular}

Tabel 2. Jumlah perhitungan semi-kuantatif Blastocystis hominis berdasarkan Jumlah total masing kelompok umur

\begin{tabular}{lccccr}
\hline \multirow{2}{*}{ Umur } & \multicolumn{3}{c}{ Jumlah $B$. hominis / LPB } & \multicolumn{2}{c}{ Total } \\
\cline { 3 - 6 } $0-<20$ & +1 & +2 & +3 & +4 & 31 \\
$21-60$ & 7 & 18 & 6 & 0 & 295 \\
$>60$ & 47 & 149 & 95 & 4 & 89 \\
Tidak ada data & 12 & 47 & 27 & 3 & 25 \\
Total & 4 & 13 & 8 & 0 & 440 \\
\hline
\end{tabular}

Sampel terbanyak berasal dari kelompok usia 21-60 tahun yaitu 67\% dari total sampel positif, sedangkan sampel yang berasal dari kelompok umur 0-20 tahun merupakan yang paling sedikit ditemukan B. Hominis yaitu hanya 7\%. Dari hasil penghitungan semi kuantitatif dengan metode mikroskopik dengan pembesaran $400 \times$, sampel yang mengandung 11-100 parasit/100 LPB (+2) merupakan yang tersering ditemukan dan paling jarang pada sampel yang mengandung parasit >10/1 LPB (+4) Tabel 2).

Tabel 3. Blastocystis hominis berdasarkan konsistensi dan perhitungan semi kuantitatif

\begin{tabular}{llcccc}
\hline & & \multicolumn{4}{c}{ Jumlah B. hominis / LPB } \\
& & $+1(\%)$ & $+2(\%)$ & $+3(\%)$ & $+4(\%)$ \\
\hline \multirow{3}{*}{ Konsistensi } & Cair & $29(41,43)$ & $100(45,37)$ & $70(52,94)$ & $5(71,43)$ \\
& Lembek & $25(35,71)$ & $91(41,85)$ & $58(42,65)$ & $1(14,29)$ \\
\multirow{3}{*}{ Total } & Padat & $9(12,86)$ & $25(11,01)$ & $4(2,94)$ & $0(0)$ \\
& Tidak ada data & $7(10,00)$ & $4(1,76)$ & $2(1,47)$ & $1(14,29)$ \\
\hline
\end{tabular}

Blastocystis hominis paling sering didapatkan pada konsistensi feses yang cair, sedangkan pada konsistensi padat jumlah $B$. hominis lebih jarang ditemukan, hal tersebut dapat dilihat pada Tabel 3.

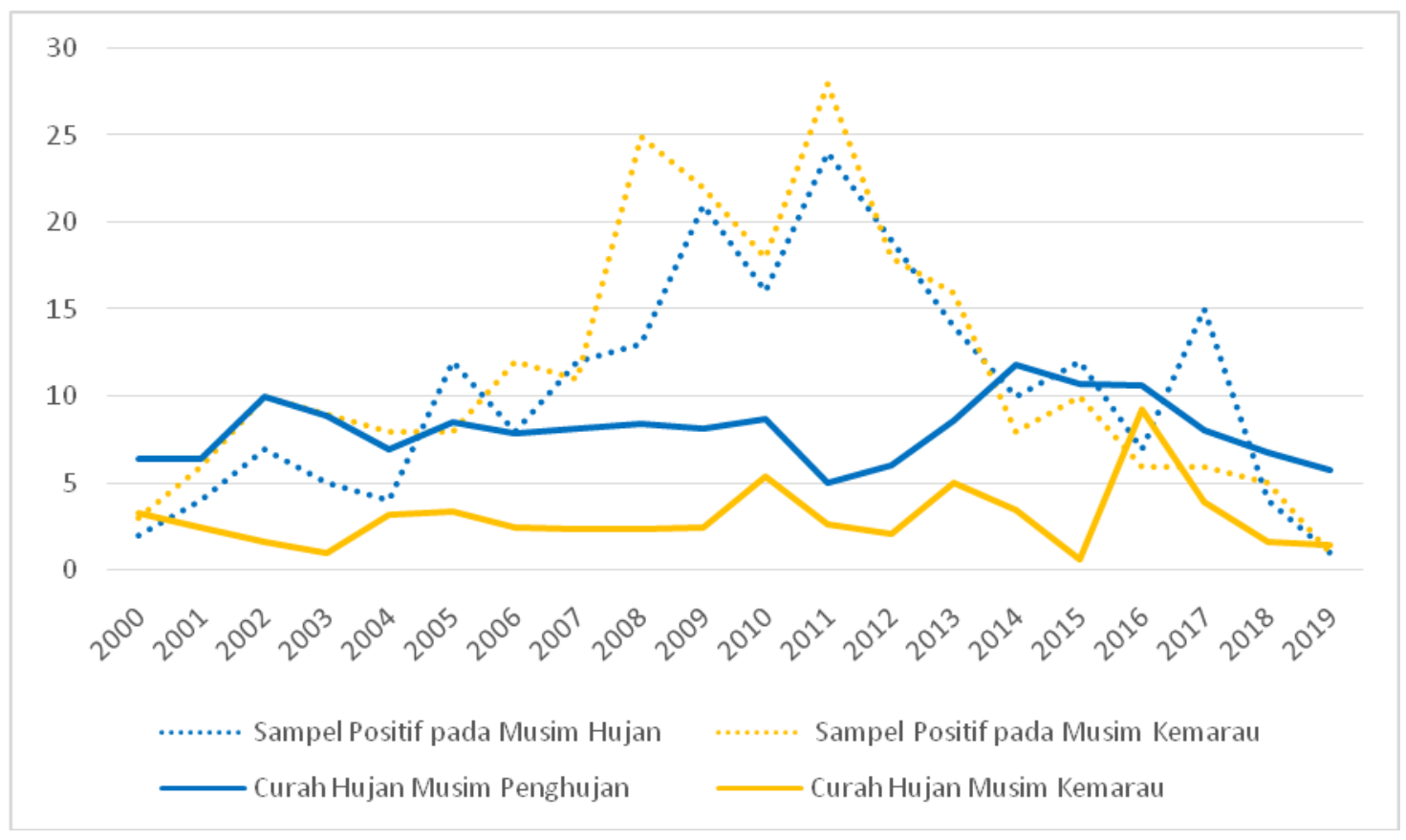


Grafik 2. Grafik hubungan antara jumlah sampel yang positif mengandung B. hominis yang didapatkan pada musim penghujan (garis biru) dan kemarau (garis kuning) dengan curah hujan pada musim penghujan (titik-titik biru) dan musim kemarau (titik kuning).

Pada Grafik 2 tampak curah hujan tertinggi pada musim penghujan terjadi di tahun 2014 yaitu sebanyak $11,8 \mathrm{~mm}$ terendah di tahun 2011 yang hanya $5 \mathrm{~mm}$, sedangkan di musim kemarau pada tahun 2016 tercatat curah hujan tertinggi dalam 20 tahun yaitu sebanyak 9,2 $\mathrm{mm}$ dan terendah pada tahun 2015 yaitu hanya $0,6 \mathrm{~mm}$. Rerata curah hujan di Daerah Khusus Ibukota (DKI) Jakarta selama 20 tahun tersebut adalah 8,075 $\mathrm{mm}$ pada musim penghujan dan 2,985 mm pada musim kemarau.

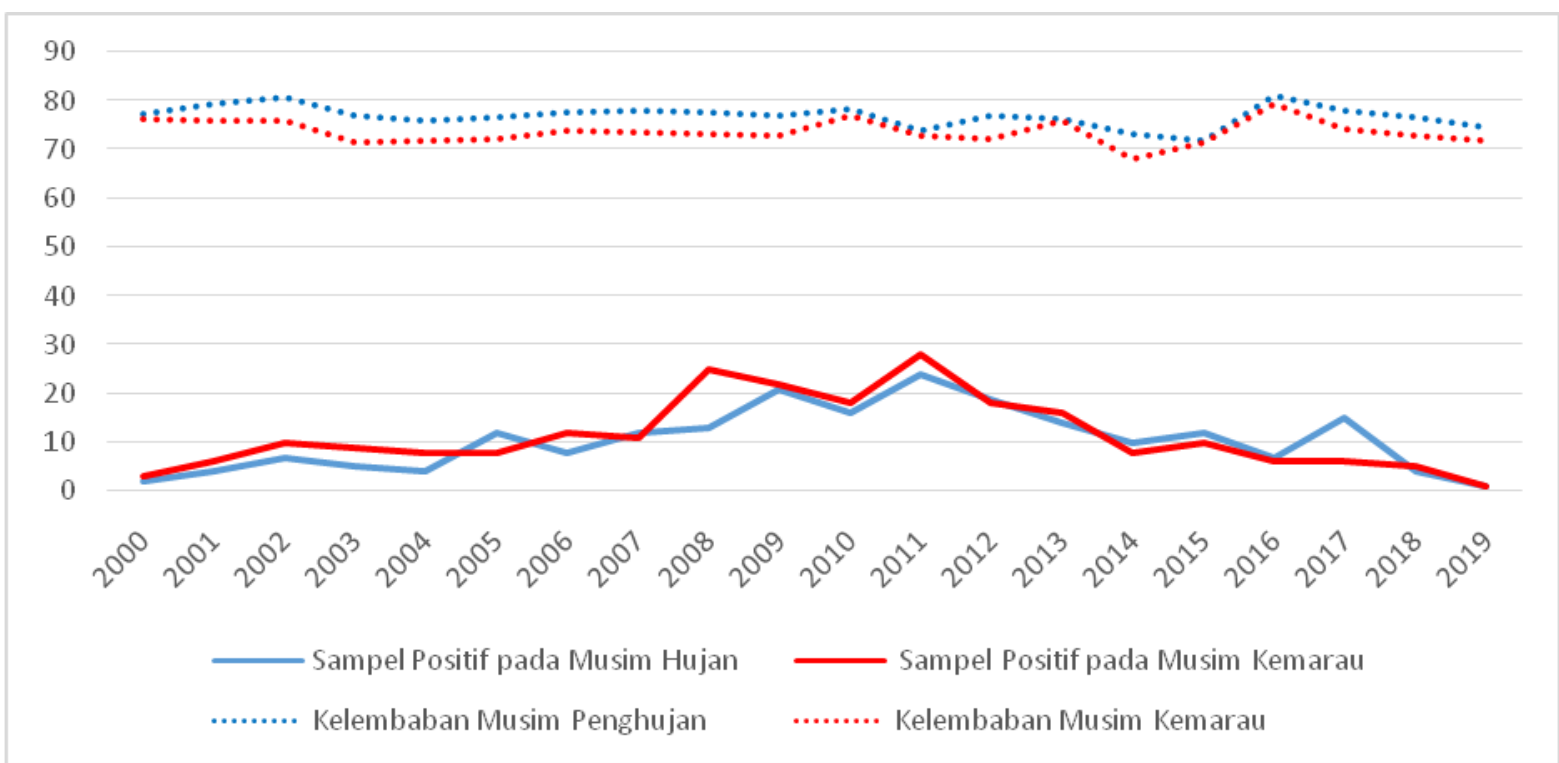

Grafik 3. Grafik hubungan antara jumlah sampel yang positif mengandung B. hominis yang didapatkan pada musim penghujan (garis biru) dan kemarau (garis merah) dengan kelembaban pada musim penghujan (titik-titik biru) dan musim kelembaban (titik merah).

Grafik 3 menampilkan jumlah sampel dan persentase kelembaban selama 20 tahun, persentase tertinggi kelembaban pada musim penghujan terjadi di tahun 2016 yaitu sebesar $81 \%$ dan terendah pada tahun 2015 sebesar 71,9\%. Kelembaban tertinggi di musim kemarau tercatat juga di tahun 2016 sebesar 79,4\% dan terendah pada tahun 2015 dengan persentase kelembaban $71,2 \%$.

\section{Pembahasan}

Walaupun B. Hominis merupakan parasit intestinal yang paling sering ditemukan namun perannya sebagai parasit patogen masih dipertanyakan. Prevalensi blastokistosis sangat beragam antara 10-60\% diseluruh dunia dan diderita oleh anak-anak dan juga dewasa. ${ }^{317,18}$ Pada kelompok dewasa, seperti pada penelitian Fletcher et al., ${ }^{19}$ yang dilakukan di daerah Afrika Sub-Sahara, Cryptosporidium spp. dan Blastocystis spp., merupakan penyebab dominan pada penderita dewasa.

Pada penelitian ini didapatkan prevalensi blastokistis sebesar $14 \%$ dalam periode waktu 20 tahun dan bervariasi antar tahun. Prevalensi tertinggi didapatkan pada tahun 2015 (21\%) dan terendah pada tahun 2019 (5\%) dengan sampel yang berasal dari kelompok umur 21-60 tahun merupakan sampel terbanyak yang ditemukan B. hominis yaitu sebanyak $295(67,4 \%)$ sampel.

Blastokistosis sering dihubungkan dengan gangguan gastrointestinal seperti diare yang berlendir, muntah, kram abdominal dan kembung., ${ }^{2,5,20-22}$ Patofisiologi diare pada $B$. hominis hingga saat ini belum diketahui dengan pasti, dan seringkali oleh sebagian laboratorium 
dianggap bukan sebagai agen protozoa penyebab. ${ }^{6,19}$ Babcock et al. ${ }^{23}$ di tahun 1985 dan juga Shlim et al., ${ }^{24}$ di tahun 1995 yang melakukan penelitian di Kathmandu, Nepal menyimpulkan bahwa $B$. hominis dianggap bukan sebagai penyebab diare pada wisatawan yang mengalami diare walau didapatkan $B$. hominis pada sampel feses para wisatawan tersebut. Saat ini, beberapa penelitian molekular menemukan bahwa beberapa sub-tipe (ST) B. hominis diketahui memiliki sifat patogen, yaitu pada ST 3, 4 dan 7 dan dapat menyebabkan diare terutama pada ST $4 .{ }^{9,19,22,25,26}$ Pada sampel feses dengan konsistensi cair, B. hominis akan lebih banyak ditemukan $(46,4 \%)$ dan menurun persentasenya pada konsistensi lembek $(39,8 \%)$ atau padat $(8,64 \%)$, hal ini terjadi karena $B$. hominis lebih mampu bertahan hidup pada kondisi lingkungan yang menguntungkan, dalam hal ini adalah konsistensi feses yang cair.

Peranan blastokistosis pada manusia masih menjadi perdebatan, hal ini disebabkan parasit ini secara umum dapat ditemukan baik pada individu yang memiliki gejala maupun yang tidak. Perdebatan tentang interpretasi blastokistosis sebagai agen patogen atau non-patogen membuat beberapa laboratorium tidak menempatkan $B$. hominis sebagai mikro-organisme prioritas dan seringkali keberadaannya tidak dilaporkan bila ditemukan parasit ini pada feses. ${ }^{18}$

Indonesia merupakan daerah tropis dengan dua musim yaitu musim penghujan dan kemarau. Kedua musim tersebut berbeda di daerah-daerah sesuai dengan letak geografis dan ketinggian di atas permukaan laut. Di Jakarta, tempat penelitian ini di lakukan, musim penghujan terjadi antara bulan Oktober hingga Maret, sedangkan musim kemarau terjadi pada bulan April hingga September. Rerata curah hujan di Jakarta menurut Stasiun Meteorologi Kemayoran selama 20 tahun ini adalah $8,1 \mathrm{~mm}$ pada musim penghujan dan $3 \mathrm{~mm}$ pada musim kemarau. ${ }^{16}$ Curah hujan pada musim penghujan tertinggi terjadi pada tahun 2014 dan terendah pada tahun 2011, sedangkan pada musim kemarau, tahun 2016 merupakan tahun saat curah hujan tercatat sebagai yang tertinggi dari kurun waktu 2000-2019 dan tahun 2015 merupakan tahun dengan curah hujan terendah.

Suresh dan Smith ${ }^{14}$ melaporkan bahwa angka kejadian blastokistosis akan meningkat saat curah hujan berkurang dan kista dari B. hominis dapat terbawa angin kemudian menyebar dan menjadi sumber penularan bagi individu lain. Sementara Salehi et al. ${ }^{15}$ melaporkan prevalensi blastokistosis terjadi tertinggi pada musim semi $(32,2 \%)$ namun hasil tersebut secara statistik tidak signifikan dibandingkan dengan prevalensi blastokistosis saat musim dingin $(22,2 \%, p=0,09)$ dan saat musim panas $(22 \%, p=0,08)$. Penelitian Salvador $e t a l^{27}$ juga melaporkan prevalensi yang lebih tinggi pada musim semi dengan persentase $30,92 \%$ dan tidak jauh berbeda dengan persentase angka kejadian pada musim panas dan musim gugur (29,33\% dan 22,56\% masing-masing).

Pada penelitian ini perbandingan prevalensi blastokistosis berdasarkan musim pertahun tidak signifikan secara statistik $(p=0,285)$. Hal ini dapat terlihat dari grafik 2 bahwa jumlah sampel B.hominis yang ditemukan saat tahun dengan curah hujan rendah tidak selalu lebih tinggi dibandingkan dengan saat curah hujan yang tinggi. Memang terlihat pada tahun 2011 saat curah hujan saat musim penghujan dan kemarau rendah, jumlah sampel positif $B$. hominis meningkat, tetapi pada tahun 2008 dan 2009, saat curah hujan di kedua musim tampak stabil, prevalnesi blastokistosis juga meningkat, kontras dengan tahun 2015 saat curah hujan pada musim kemarau merupakan yang terendah dalam periode 20 tahun, angka kejadian blastokistosis bahkan lebih rendah dibandingakan musim penghujan yang curah hujan saat itu berada di atas rerata.

Faktor kelembaban pada penelitian ini juga tidak signifikan $(p=0,204)$ terhadap hubungan dengan kejadian blastoksitosi. Kemungkinan hal ini disebabkan kelembaban rata-rata di DKI Jakarta tidak berbeda jauh saat musim penghujan yaitu 71,9 hingga $81,0 \%$ dan musim kemarau antara 67,9 hingga $77 \% .{ }^{16}$ Hingga kini belum ditemukan laporan penelitian yang 
menyebutkan faktor kelembaban sebagai faktor predisposisi angka kejadian blastokistosis. Abdulsalam et al. ${ }^{12}$ dan Alfellani et $a .^{2}$ dalam penelitiannya mengatakan udara kering dapat meningkatkan angka kejadian $B$. hominis. Perpaduan antara suhu yang tinggi dan kering dapat membantu transmisi penyebaran kista $B$. hominis pada lingkungan yang berdebu. ${ }^{12}$

\section{Kesimpulan}

Prevalensi blastokistosis yang didapatkan dari pemeriksaan di Laboratorium Parasitologi FK UKI selama 20 tahun adalah $14 \%$ dari seluruh bahan klinik feses yang diperiksa dan merupakan protozoa yang paling sering ditemukan pada sampel feses. Konsistensi feses yang cair akan membantu daya tahan hidup $B$. hominis sehingga lebih mudah mendapatkan $B$. hominis pada sampel. Curah hujan dan kelembaban di DKI Jakarta tidak berperan terhadap angka kejadian $B$. hominisdikarenakan perbedaan antara jumlah curah hujan dan persentase kelembaban saat musim penghujan dan musim kemarau tidak terlalu ekstrim.

\section{Daftar Pustaka}

1. Belleza MLB, Cadacio JLC, Borja MP, Solon JAA, Padilla MA, Tongol-Rivera PN, et al. Epidemiologic study of Blastocystis infection in an urban community in the Philippines. J Environ Public Heal. 2015;2015:1-5.

2. Alfellani MA, Stensvold CR, Vidal-Lapiedra A, Onuoha ESU, Fagbenro-Beyioku AF, Clark CG. Variable geographic distribution of Blastocystis subtypes and its potential implications. Acta Trop. 2013;126(1):118.

3. Wong KHS, Ng GC, Lin RTP, Yoshikawa H, Taylor MB, Tan KSW. Predominance of subtype 3 among Blastocystis isolates from a major hospital in Singapore. Parasitol Res. 2008;102(4):663-70.

4. Muflihatun T, Bernadus JBB, Wahongan GJP. Perbandingan deteksi Blastocystis hominis dengan pemeriksaan copro ELISA. eBm. 2015;3(1):355-8.

5. Nofita E, Harminarti N, Rusjdi SR. Identifikasi Blastocystis hominis secara mikroskopis dan PCR pada sampel feses di Laboratorium RSUP DR M. Djamil Padang. MKA. 2014;37(94).

6. Basak S, Rajurkar MN, Mallick SK. Detection of Blastocystis hominis: A controversial human pathogen. Parasitol Res. 2014;113(1):261-5.

7. Tan TC, Suresh KG, Smith H V. Phenotypic and genotypic characterisation of Blastocystis hominis isolates implicates subtype 3 as a subtype with pathogenic potential. Parasitol Res. 2008;104(1):85-93.

8. Nieves-Ramirez ME, Partida-Rodriguez O, Laforest-Lapointe LA, Reynolds LA, Brown EM, Morien E, et al. Asymptomatic intestinal colonization with protist Blastocystis is strongly associated with distinct microbiome ecological patterns. mSystems. 2018;3(3):1-18.

9. Scanlan PD, Stensvold CR, Rajilić-Stojanović M, Heilig HGHJ, De Vos WM, O'Toole PW, et al. The microbial eukaryote Blastocystis is a prevalent and diverse member of the healthy human gut microbiota. FEMS Microbiol Ecol. 2014;90(1):326-30.

10. Krogsgaard LR, Engsbro AL, Stensvold CR, Nielsen HV, Bytzer P. The prevalence of intestinal parasites is not greater among individuals with irritable bowel syndrome: A population-based case-control study. Clin Gastroenterol Hepatol. 2015;13(3):507-13.

11. Zhang SX, Yang CL, Gu WP, Ai L, Serrano E, Yang P, et al. Case - control study of diarrheal disease etiology in individuals over 5 years in southwest China. Gut Pathog. 2016;8:1-11.

12. Abdulsalam AM, Ithoi I, Al-Mekhlafi HM, Khan AH, Ahmed A, Surin J, et al. Prevalence, predictors and clinical significance of Blastocystis sp. in Sebha, Libya. Parasite Vectors. 2013;6(1):4-11.

13. Paboriboune P, Phoumindr N, Borel E, Sourinphoumy K, Phaxayaseng S, Luangkhot E, et al. Intestinal parasitic infections in HIV-infected patients, Lao People's Democratic Republic. PLoS One. 2014;9(3):1-8.

14. Suresh K, Smith H. Comparison of methods for detecting Blastocystis hominis. Eur J Clin Microbiol Infect Dis. 2004;23(6):509-11.

15. Salehi R, Haghighi A, Stensvold CR, Kheirandish F, Azargashb E, Raeghi S, et al. Prevalence and subtype identification of Blastocystis isolated from humans in Ahvaz, Southwestern Iran. Gastroenterol Hepatol from Bed Bench. 2017;10(3):235-41.

16. Badan Meteorologi Klimatologi dan Geofisika. Data online pusat database BMKG [Internet]. 2020 [diunduh dari https://dataonline.bmkg.go.id/akses_data 18 September 2020

17. Londoño A, Mejía S, Gómez-Marín J. Prevalence and risk factors associated with intestinal parasitism in preschool children from the urban area of Calarcá, Colombia. Rev Salud Publica. 2009;11(1):72-81.

18. Fletcher SM, McLaws M-L, Ellis JT. Prevalence of gastrointestinal pathogens in developed and developing 
countries: systematic review and meta-analysis. J Public Heal Res. 2013;2(1):9.

19. Fletcher SM, Stark D, Ellis J. Prevalence of gastrointestinal pathogens in sub-saharan africa: Systematic review and meta-analysis. J Public Heal Africa. 2011;2(2):127-37.

20. Pramestuti N, Saroh D. Blastocystis hominis: Protozoa usus potensial penyebab diare. J Penelit Kesehat. 2012. p. 1-12.

21. Coyle CM, Varughese J, Weiss LM, Tanowitz HB. Blastocystis: To treat or not to treat.. Clin Infect Dis. 2012;54(1):105-10.

22. Fletcher SM, Stark D, Harkness J, Ellis J. Enteric protozoa in the developed world: A public health perspective. Clin Microbiol Rev. 2012;25(3):420-49.

23. Babcock D, Houston R, Kumaki D, Shlim DR. Blastocystis hominis in Kathmandu, Nepal. N Engl J Med. 1985;313(22):1419.

24. Shlim DR, Hoge CW, Rajah R, Rabold JG, Echeverria P. Is Blastocystis hominis a cause of diarrhea in travelers? a prospective controlled study in Nepal. Clin Infect Dis. 1995;21(1):97-101.

25. Stensvold CR, Christiansen DB, Olsen KEP, Nielsen HV. Blastocystis sp. subtype 4 is common in Danish Blastocystis-positive patients presenting with acute diarrhea. Am J Trop Med Hyg. 2011;84(6):883-5.

26. Roberts T, Stark D, Harkness J, Ellis J. Subtype distribution of Blastocystis isolates identified in a Sydney population and pathogenic potential of Blastocystis. Eur J Clin Microbiol Infect Dis. 2013;32(3):335-43.

27. Salvador F, Sulleiro E, Sánchez-montalvá A, Alonso C, Santos J, Fuentes I, et al. Epidemiological and clinical profile of adult patients with Blastocystis sp. infection in Barcelona, Spain. Parasit Vectors. 2016;17. 